\title{
PENGARUH NYANYIAN LITURGI “BBT” TERHADAP PARTISIPASI KAUM MUDA DALAM PERAYAAN EKARISTI
}

\author{
Antonius Joko Hermawan
}

\begin{abstract}
Abstrak:
In 2009, Commission for Liturgy of the Archdiocese of Semarang published a liturgical songbook for the youth: Bernyanyilah Bagi Tuhan (BBT). The author is interested in answering a question: have liturgical songs in BBT responded to the needs of the youth and affected their understanding of faith? To answer this question, the author has conducted a field research by using qualitative research methods. To obtain relevant data, the authors conducted an in-depth interview with fifteen participants. The findings reveal positive signs that the BBT songs have met the needs of the youth through singing those songs for the youth. The songs also prove to affect their understanding of faith. Its significant influence is clearly seen from the participations of youth in various Eucharistic celebrations. Through those songs, young people are helped to express their faith physically and spiritually by way of singing in a Eucharist.
\end{abstract}

Kata-kata Kunci:

potensi, fungsi, partisipasi, sosialisasi, inkulturasi, paguyuban, pendidikan liturgi.

\section{LATAR BELAKANG DAN FENOMENA UMUM}

Komisi Liturgi Keuskupan Agung Semarang (Komlit KAS) telah menerbitkan buku nyanyian liturgi untuk kaum muda Bernyanyilah Bagi Tuhan (BBT). Buku nyanyian liturgi yang disusun sejak tahun 2009 oleh tim penyusun BBT tersebut, merupakan usaha Komlit KAS dalam rangka menyediakan khasanah nyanyian liturgi baru yang baik untuk digunakan dalam perayaan liturgi. Upaya tersebut dilakukan untuk menjawab keprihatinan kurangnya khasanah nyanyian liturgi, khususnya bagi kaum muda. Bagi orang muda khasanah nyanyian liturgi yang ada pada waktu itu dianggap sudah terlalu kuno. ${ }^{1}$ Oleh karena itu mereka berupaya mencari dan menggunakan nyanyian-nyanyian yang dianggap mampu menyentuh jiwa muda mereka untuk digunakan dalam perayaan liturgi, khususnya perayaan Ekaristi. Akibatnya, banyak nyanyian-nyanyian populer yang masuk dalam perayaan Ekaristi. Bahkan terjadi penggunaan nyanyian-nyanyian yang tema dan isi syairnya tidak sesuai sama sekali dengan perayaan yang sedang dilaksanakan. 
Pada sisi yang lain, di kalangan kaum muda sendiri telah muncul berbagai kreativitas untuk menciptakan nyanyiannyanyian dengan maksud bisa digunakan dalam perayaan Ekaristi. Hal itu kiranya juga dipengaruhi oleh ciri-ciri potensi yang dimiliki oleh orang muda, yakni: ${ }^{2}$

a) Dinamis penuh dengan gairah dan semangat hidup yang membara. Jiwa muda adalah jiwa dalam 'taufan dan badai' (sturm and drang), sarat dengan gelora hidup yang harus menemukan penyaluran yang tepat. Ciri ini mendorong mereka untuk berpetualang dan bereksperimen dalam upaya mencari nilai-nilai baru, karena tidak mau didikte oleh zamannya atau oleh generasi pendahulu. Dorongan emosi yang meluap-luap tidak jarang mendorong mereka cepat bereaksi dan bertindak tanpa pikir panjang.

b) Berorientasi masa depan. Berbeda dengan generasi tua yang umumnya suka mengenang dan merindukan masa silam (pastoriented), generasi muda cenderung berorientasi ke masa depan (future-oriented).

c) Terbuka terhadap setiap perkembangan dan pembaruan, yang dianggap dapat mempercepat proses realisasi masa depan yang didambakan. Potensi ini menempatkan orang muda sebagai generasi 'pembaru' yang selalu berupaya melawan kemapanan dan mendobrak nilai-nilai lama yang melestarikan status quo.

d) Kreatif: karena tidak puas dengan keadaan dan nilai-nilai lama dan haus akan segala sesuatu yang baru, mereka selalu mengerahkan daya-cipta untuk mencari terobosan-terobosan baru.

e) Empatik: orang muda juga memiliki kepekaan sosial yang tinggi sehingga dengan cepat dan mudah ikut merasakan penderitaan orang lain.

Ciri-ciri potensi tersebut mendorong orang muda untuk berkreasi demi memenuhi hasrat jiwa muda mereka. Salah satunya adalah dengan menciptakan nyanyiannyanyian liturgi yang baru. Oleh karena itu, selain terdapat nyanyian liturgi yang sudah ada dalam buku Madah Bakti (MB) dan Puji Syukur (PS), di kalangan umat muncullah nyanyian-nyanyian baru yang digunakan dalam perayaan Ekaristi. Namun sayangnya, dari beberapa nyanyian baru yang diciptakan orang muda itu, ada kalanya ditemukan kurang sesuai dengan kriteria sebagai nyanyian liturgi.

Dari latar belakang dan fenomena tersebut di atas, tulisan ini mencoba menjawab persoalan apakah nyanyian liturgi yang baru mampu mendorong pertisipasi orang muda dalam perayaan Ekaristi? Untuk menjawab persoalan tersebut, sebelumnya penulis telah melakukan penelitian kecil terhadap beberapa orang muda aktivis kor yang telah menggunakan nyanyian liturgi kaum muda dari buku BBT. Dalam penelitian tersebut disimpulkan bahwa orang muda sangat membutuhkan adanya nyanyian liturgi baru yang berjiwa muda. Bahkan kehadiran nyanyian liturgi BBT dirasa mampu memberi suasana dalam perayaan Ekaristi yang berbeda dari biasanya.

\section{KERINDUAN DAN HARAPAN KAUM MUDA TERHADAP TRADISI MUSIK LITURGI}

Kaum muda sebagai insan masa depan Gereja memiliki harapan terhadap perkembangan musik liturgi. Harapan tersebut terungkap dari hasil wawancara mendalam yang telah penulis lakukan dalam penelitian. Orang muda berharap bahwa khasanah nyanyian liturgi yang baru semakin diperbanyak. Mereka merasa bahwa perbendaharaan nyanyian yang sudah ada selama ini monoton dan membosankan. Bagi mereka perlu ada banyak nyanyian liturgi baru sebagai alternatif pilihan untuk digunakan dalam perayaan Ekaristi.

Orang muda juga berharap adanya penggunaan berbagai alat musik yang bisa digunakan untuk mengiringi nyanyian liturgi dalam perayaan Ekaristi. Meskipun demikian mereka juga sadar bahwa penggunaan alat musik perlu disesuaikan dengan tema dan suasana yang dibangun dalam perayaan liturgi. Terhadap tradisi musik liturgi Gereja, orang muda pada dasarnya tidak antipati terhadap nyanyian liturgi klasik, seperti misalnya nyanyian Gregorian. Namun, untuk menciptakan suasana yang dinamis mereka berharap supaya penggunaan nyanyian liturgi bisa 
bergantian antara yang klasik dan yang modern.

Terhadap pengembangan musik liturgi saat ini, orang muda mengharapkan adanya proses sosialisasi yang tegas dan jelas dari pihak-pihak yang bertanggung jawab, misalnya tim kerja liturgi dan kor paroki. Tim liturgi paroki perlu mendorong umat untuk semakin mengenal dan menggunakan lagu-lagu liturgi baru. Adanya sosialisasi yang tegas dan jelas akan mendukung umat khususnya orang muda untuk tidak takut memilih dan menyanyikan lagu-lagu liturgi yang baru. Sosialisasi juga harus menyentuh persoalan pemahaman orang muda terhadap nyanyian liturgi, sebab selama ini masih banyak umat khususnya orang muda yang tidak tahu makna nyanyian liturgi, bahkan masih ada perdebatan di kalangan umat terhadap nyanyian mana yang boleh digunakan dan mana yang tidak boleh digunakan untuk Misa. Harapan yang lain tentang nyanyian liturgi selanjutnya adalah bahwa lagu-lagu liturgi untuk orang muda hendaknya bernuansa hidup, ramai, dengan gaya yang gaul, dan bersemangat. Maka bagi mereka nyanyian liturgi kaum muda akan semakin hidup bila diiringi dengan berbagai iringan alat musik dan tidak sekadar diiringi dengan organ saja.

\section{FUNGSI MUSIK LITURGI BAGI ORANG MUDA}

Pertanyaan tentang peran/fungsi musik dalam konstitusi liturgi Sacrosanctum Concilium artikel 112 dan instruksi Musicam Sacram menempati tempat utama dalam pemikiran Gereja. Pertanyaan ini merupakan jantung/inti dari seluruh reformasi liturgi, khususnya persoalan terkait musik dan nyanyian. Dalam liturgi, peran/fungsi pelayanan seseorang atau sesuatu adalah untuk melayani komunitas liturgi. ${ }^{3}$ Oleh karena itu upacara dan nyanyian merupakan liturgi sendiri sejauh memenuhi fungsi melayani atau sebagai pelayan liturgi. ${ }^{4}$ Jika tidak, maka liturgi akan kering dan terasa kosong dan akan segera ditinggalkan/mati dalam perjalanan sejarah.

Musik liturgi adalah musik yang mengungkapkan makna penting dari ritual dan mengandung makna yang penuh dari liturgi. ${ }^{5}$ Dari jenisnya, fungsi musik liturgi dapat dibagi dalam beberapa kemungkinan: ${ }^{6}$

a) Musik sebagai kegiatan liturgis, misalnya: sebagai aklamasi/dialog antara imam dan umat, sebagai pewartaan dan renungan (Mazmur Tanggapan), sebagai syukur (Kemuliaan, Kudus, Madah Syukur sesudah Komuni), sebagai doa permohonan (Tuhan Kasihanilah Kami, Bapa Kami, Anak Domba Allah), dan sebagai pernyataan iman (Syahadat Iman, Anamnesis).

b) Musik untuk mengiringi suatu kegiatan liturgis, yakni untuk mengungkapkan apa yang terjadi, misalnya: perarakan (nyanyian pembuka, bait pengantar Injil, dan nyanyian penutup), kegiatan persiapan persembahan dari perarakan sampai pendupaan altar, pemecahan roti (nyanyian Anak Domba Allah), mempersatukan umat dalam Perjamuan Tuhan (nyanyian komuni), pembasuhan kaki (pada Kamis Putih), penyembahan salib (pada Jumat Agung), dsb.

c) Dari segi antropologis, musik liturgi juga berfungsi sebagai pemersatu. Dengan bernyanyi bersama umat dipersatukan (misalnya dalam nyanyian pembuka). Selain itu melalui musik dan nyanyian, sebuah perayaan diperindah bagaikan keindahan surga. Hal ini berdasar pada pernyataan Konstitusi Liturgi: "Dalam liturgi di dunia ini kita ikut mencicipi liturgi surgawi" (SC 8), maka selayaknyalah bentuk perayaan dan tingkat partisipasi umat bervariasi sebanyak mungkin sesuai dengan kemeriahan pesta dan keadaan umat yang hadir (MS 10). Liturgi yang bersifat suci memerlukan dukungan kesenian (khususnya musik) yang mau melebur dalam kesucian liturgi.7 Oleh karenanya bisa dikatakan bahwa bentuk dan isi dari musik liturgi ditentukan oleh bentuk dan urutan liturgi yang berbobot suci.

Instruksi musik liturgi Musicam Sacram (5 Maret 1967) menyatakan beberapa hal sebagai berikut:

Kebaktian liturgis memperoleh bentuk yang lebih mulia dan indah apabila dirayakan dengan nyanyian, dengan para 
pelayan dari setiap tingkatan menunaikan tugasnya dan umat turut serta di dalamnya. Melalui bentuk seperti ini, doa-doa diungkapkan dengan cara yang lebih menarik, misteri liturgi dengan sifat hakiki hirarkis dan persekutuannya dipamerkan secara lebih terbuka, persatuan segala hati bisa dicapai dengan lebih mendalam lagi oleh persatuan suara-suara, pikiran dengan lebih mudah dilayangkan ke hal-hal surgawi oleh keindahan upacara suci, dan seluruh perayaan menggambarkan secara lebih jelas lagi liturgi surgawi yang dipentaskan dalam kota suci Yerusalem (MS 5). ${ }^{8}$

Dalam Instruksi di atas Joncas menemukan lima fungsi musik liturgi yang dapat dipetakan sebagai berikut: ${ }^{9}$

\section{Fungsi Dekoratif}

Dengan dinyanyikan, sebuah doa diungkapkan dengan lebih menarik dan anggun. Nyanyian akan menambah keanggunan suatu ungkapan doa dan secara psikologis memberi pengaruh terhadap emosi seseorang, baik yang menyanyikan maupun yang mendengarnya. Untuk perasaan ini, Yohanes Paulus II menyatakan bahwa sikap takjub dan penuh rasa kagum dari orang yang mendengarkan atau menyanyikan musik, akan memunculkan antusiasme untuk mengangkat diri dan memulai lagi hidupnya. ${ }^{10}$ Dalam arti ini keindahan akan menyelamatkan dunia.

\section{Fungsi Diferensiatif}

Misteri liturgi yang sedari hahikatnya bersifat hierarkis dan komunitas jemaat, dinyatakan secara lebih jelas dan tampak ketika ditopang dengan musikalitas.

\section{Fungsi Unitatif}

Musik itu mempersatukan jemaat dan kesatuan hati dicapai secara lebih mendalam berkat perpaduan suara.

\section{Fungsi Transendental}

Musik yang suci itu seperti mempercantik liturgi surgawi. ${ }^{11}$ Melalui musik, hati lebih mudah dibangkitkan ke arah hal-hal surgawi berkat keindahan upacara kudus. Dalam suratnya kepada para artis, Yohanes Paulus II menyatakan bahwa yang "indah" terpadu dengan yang "benar" sehingga melalui kesenian pun jiwa-jiwa dapat diangkat dari alam rasa-perasaan kepada alam abadi. ${ }^{12}$ Hal ini terjadi karena keindahan musik liturgi yang dimantabkan oleh aliran jernih Injil, di mana Kristus menjadi satusatunya kesenian dan seni musik yang sejati.

\section{Fungsi Eskatologis}

Musik bukan sekadar membantu menciptakan suasana keilahian, melainkan juga menjadi pralambang liturgi surgawi, yang disemarakkan dengan nyanyian para malaikat dan yang akan kita alami pada akhir zaman.

Dari penelitian yang penulis lakukan, orang muda pada umumnya masih menempatkan musik liturgi sebatas pada fungsi dekoratifnya saja. Hal itu berarti bahwa orang muda menganggap nyanyian liturgi yang bagus adalah nyanyian yang enak untuk dinyanyikan maupun didengarkan, atau menyentuh hati dan pengalaman mereka. Maka meskipun ada nyanyian yang baik dalam arti memiliki fungsi deferensiatif, unitatif, transcendental, dan eskatologis, tetapi tidak enak atau susah dinyanyikan, mereka cenderung meninggalkannya. Dalam hal ini kebanyakan orang muda belum menyadari pentingnya fungsi-fungsi lain (deferensiatif, transendental, unitatif, dan eskatologis) yang dimiliki musik atau nyanyian liturgi. Hal ini menunjukkan bahwa pemahaman orang muda terhadap nyanyian liturgi masih sangat kurang.

\section{UPAYA INKULTURASI DALAM NYANYIAN LITURGI KAUM MUDA}

Joseph Gelineau pernah menyatakan bahwa perkembangan bahasa musik serta teknologinya kebanyakan menyebabkan semacam 'kekagetan' serta kesan aneh bagi para pendengar pada saat musik semacam itu didengar pertama kalinya. ${ }^{13}$ Menurutnya kesan tersebut dapat memunculkan kebingungan dan ketidakjelasan arti dari simbolsimbol dalam liturgi. Terhadap pendapat seperti itu, Dieter Mack memberi catatan bahwa simbol-simbol musik pada umumnya bersifat relatif (tergantung konteks) pada masa kini. ${ }^{14}$ Menurut Mack, tidak mustahil bahwa choral Gregorian ${ }^{15}$ juga dianggap 
aneh, karena sudah tidak sesuai dengan yang terasa "biasa" oleh masyarakat modern, apalagi bagi kaum muda zaman sekarang. Bagi orang muda zaman sekarang musik liturgi yang baru seakan-akan mesti bertolak dari budaya musik popular, karena inilah yang paling diketahui dan dinikmati oleh kebanyakan orang muda. ${ }^{16}$

Ciri dinamis dan terbuka terhadap setiap perkembangan serta pembaruan membuat orang muda senang dan menerima kehadiran sesuatu hal yang baru. Bagi mereka hal-hal yang baru dianggap sebagai sesuatu yang menantang, bermuatan masa depan, dan tidak ketinggalan zaman. Sesuatu yang baru itu menarik mereka untuk mempelajarinya, sehingga ketika ada nyanyian liturgi yang baru mereka sangat antusias menerimanya.

Hasil penelitian juga menunjukkan bahwa orang muda cenderung kurang tertarik dengan hal-hal yang sudah lama. Orang muda akan cepat bosan dan tidak bersemangat lagi terhadap nyanyian-nyanyian liturgi yang sudah lama, misalnya saja nyanyian liturgi yang ada dalam buku MB dan PS. Nyanyian liturgi dalam kedua buku tersebut sudah lama dikenal oleh umat. Namun, bagi orang muda nyanyian liturgi dalam MB dan PS dianggap sudah ketinggalan zaman. Hal ini menunjukkan bahwa kebutuhan nyanyian liturgi baru yang sesuai dengan jiwa orang muda sangat besar. Bagi orang muda suasana liturgi dengan adanya nyanyiannyanyian liturgi yang baru akan menjadi semakin indah, hidup, dan bersemangat. Apalagi nyanyian liturgi yang baru tersebut dapat menampung kreativitas orang muda, seperti misalnya dapat dimainkannya berbagai alat musik pada saat mengiringi nyanyian liturgi.

Alat musik organ khususnya orgel pipa sangat dijunjung tinggi dalam tradisi musik Gereja. Suara orgel pipa dianggap mampu memeriahkan upacara-upacara Gereja secara mengagumkan, dan mengangkat hati umat kepada Allah dan ke surga (SC 120). Hasil penelitian menunjukkan bahwa orang muda tidak serta-merta menolak alat musik organ. Orang muda masih tetap menghargai organ sebagai alat musik khas yang dimiliki oleh Gereja. Namun demikian, dalam pera- yaan Ekaristi mereka juga menginginkan penggunaan alat musik yang lain yang dirasa lebih modern, misalnya: gitar, flute, keyboard, kajon, dan lain-lain. Untuk persoalan ini konstitusi liturgi memberi kebijakan bahwa alat musik selain organ dapat digunakan dalam ibadat suci, sejauh memang cocok atau dapat disesuaikan dengan penggunaan dalam liturgi, sesuai pula dengan keanggunan gedung gereja, dan sungguh membantu memantapkan penghayatan umat beriman. Tentu saja penggunaan alat musik juga harus mendapat persetujuan dan kebijakan pimpinan gerejawi setempat (SC 120).

Ciri-ciri potensi orang muda yang kreatif, dinamis, berorientasi masa depan, dan terbuka terhadap setiap perkembangan dan pembaruan, semakin mendukung paham bahwa musik liturgi harus mengikuti perkembangan zaman. ${ }^{17}$ Kaum muda zaman sekarang hidup dalam suasana genre musik pop yang sangat kuat, sehingga mereka terbiasa dengan musik modern seperti itu. Maka kaum muda mengharapkan bahwa nyanyian liturgi baru hendaknya lebih dinamis dan bergaya pop. Namun demikian, Mack menilai bahwa paham generasi muda akan lebih suka pergi ke gereja jika musik liturgi sesuai dengan bahasa pop, merupakan pandangan yang terlalu sempit, sebab unsur kualitatif dan hakikat keagamaan sendiri diabaikan demi memancing orang. ${ }^{18}$

Penulis menilai apa yang disampaikan oleh Mack adalah benar, bahwa orang muda justru dapat menerima musik "avant-garde" yang dimiliki oleh Gereja, oleh karena mereka paham dan tahu bahwa musikmusik tersebut merupakan kekayaan Gereja yang sangat membanggakan di sepanjang sejarah. Namun memang tidak dapat dipungkiri bahwa jiwa kaum muda sangat membutuhkan dukungan dan sarana bagi pengungkapan iman dalam perayaan iman mereka. Oleh karena itu, dalam rangka lebih mendorong partisipasi aktif kaum muda dalam perayaan Ekaristi, Gereja senantiasa berusaha mengembangkan nyanyian liturgi kaum muda sebagai upaya inkulturasi musik liturgi dalam budaya orang muda. 
Dalam rangka inkulturasi musik liturgi, Konsili Vatikan II menyatakan bahwa dalam hal-hal yang tidak menyangkut iman atau kesejahteraan segenap umat, Gereja tidak mengharuskan keseragaman yang kaku di dalam liturgi (SC 37). Hal tersebut sangat disadari sebab dalam liturgi terdapat unsur yang tidak dapat diubah karena ditetapkan oleh Allah, maupun unsur-unsur yang dapat berubah, yang di sepanjang masa dapat atau bahkan mengalami perubahan (SC 21). Bagi penulis, musik liturgi untuk kaum muda pun juga mengalami perubahan dari zaman ke zaman. Hal ini dipengaruhi oleh perkembangan budaya musik pop yang semakin pesat di kalangan orang muda. Meski demikian, konsili menegaskan bahwa dalam perubahan tersebut harus diperhatikan pengaturannya supaya lebih jelas mengungkapkan hal-hal kudus yang dilambangkan, sehingga umat kristiani dapat menangkap dengan mudah, dan dapat ikut serta dalam perayaan secara penuh, aktif, dan dengan cara yang khas bagi jemaat.

Untuk perayaan liturgis, tidak ada jenis musik ibadat yang ditolak oleh Gereja, asal sesuai dengan jiwa perayaan liturgis itu sendiri dan selaras dengan hakikat masingmasing bagian (MS 9). Pernyataan dari instruksi Musicam Sacram tersebut menyiratkan bahwa Gereja tidak menolak berbagai jenis musik ibadat, termasuk jenis musik pop yang menjadi nuansa nyanyian liturgi kaum muda. Namun demikian, nyanyian liturgi kaum muda yang bergaya pop itu tetap harus mengutamakan jiwa perayaan liturgi dan selaras dengan hakikat masing-masing bagian liturgi. Maka dalam beberapa nyanyian liturgi yang bergaya pop, penggunaannya dalam liturgi harus disesuaikan antara tema nyanyian dengan tema atau bagian perayaan liturginya. Untuk hal ini kaum muda perlu memahaminya dengan baik, karena banyak terjadi asal itu sebuah nyanyian liturgi yang enak didengar karena bergaya pop maka dipilih. Padahal nyanyian tersebut tidak sesuai tempatnya dalam bagian liturgi, misalnya nyanyian liturgi bertema pertobatan yang dinyanyian pada saat upacara komuni.

Agar orang muda tidak asal dalam memilih nyanyian liturgi, maka perlu disediakan nyanyian liturgi kaum muda yang dapat digunakan sesuai dengan bagianbagian liturginya. ${ }^{19}$ Dalam hal ini nyanyian liturgi BBT dapat dikatakan sebagai hasil usaha inkulturasi nyanyian liturgi dalam budaya orang muda. Akhirnya buku nyanyian liturgi kaum muda BBT yang dibuat oleh tim penyusun dari Komlit KAS, disusun untuk membantu umat, khususnya kaum muda, dalam memilih nyanyian liturgi yang tepat untuk membantu mereka menyatukan diri (fungsi unitatif) dalam misteri iman yang dirayakan dalam Ekaristi.

\section{NYANYIAN LITURGI KAUM MUDA MENDORONG PARTISIPASI OMK DALAM PERAYAAN LITURGI}

Hakikat liturgi menuntut partisipasi secara penuh, sadar, dan aktif dari umat beriman yang terlibat di dalamnya (lih. SC 14). Partisipasi yang penuh secara esensial menunjuk pada partisipasi yang bukan hanya diungkapkan melalui suara dan gerak badan saja, tetapi juga seluruh pikiran dan hati (bdk. SC 11). Jadi, partisipasi secara penuh ingin menunjukkan keterlibatan umat baik secara batin, pikiran, dan hati, maupun secara lahiriah melalui suara dan gerak badan. Terkait dengan partisipasi secara sadar dan aktif, konstitusi liturgi menekankan supaya umat beriman dapat memahami misteri iman yang dirayakan dengan baik (SC 48). Partisipasi sadar terjadi ketika umat beriman yang sedang merayakan sakramen paham dan mengerti akan apa yang sedang dilakukan dalam perayaan itu. ${ }^{20}$ Umat memahami bagianbagian perayaan serta mengerti makna dari simbol-simbol liturgi yang ada. Ia paham mengapa berdiri, berlutut, berdoa, bernyanyi, bersalaman, menebah dada, dan sebagainya (lih. PUMR 47-48). Yang terutama adalah secara batin umat sadar bahwa roti yang diterima pada saat komuni adalah Tubuh Kristus sendiri (lih. PUMR 80).

Partisipasi secara sadar dan aktif juga menyangkut persiapan diri kita ketika memilih nyanyian liturgi. Para petugas liturgi khususnya kor, secara sadar tahu dan paham bahwa pemilihan nyanyian liturgi harus sesuai dengan tema perayaan dan bagian-bagiannya. Ia sadar bahwa penggunaan nyanyian dalam perayaan liturgi khususnya Ekaristi tidak boleh asal-asalan. 
Penggunaan nyanyian yang tepat akan membantu kesatuan antara apa yang dinyanyikan dengan perayaan yang sedang berlangsung. Demikianlah dengan pemilihan nyanyian yang tepat, umat beriman dapat menyesuaikan hati dengan apa yang mereka ucapkan/nyanyikan (bdk. SC 11). Konstitusi liturgi menyatakan bahwa upacara liturgi menjadi lebih agung, bila ibadat kepada Allah dirayakan dengan nyanyian meriah, bila dilayani oleh petugaspetugas liturgi, dan bila umat beriman ikut serta secara aktif (SC 113). Pernyataan tersebut menegaskan betapa pentingnya nyanyian liturgi yang tepat untuk mendukung kemeriahan upacara liturgi. Musik dapat membuat liturgi semakin hidup dan penuh sehingga umat beriman berdoa dengan sungguh-sungguh, intensif dan efektif. ${ }^{21}$

Sudah dijelaskan di atas bahwa musik liturgi membantu juga pemahaman terhadap misteri iman yang sedang dirayakan oleh umat karena memiliki fungsi transendental dan eskatologis yang sangat kuat. Tidak hanya itu perayaan liturgi akan semakin agung jika umat ikut terlibat secara aktif dan terlebih ikut bernyanyi dengan lagu-lagu liturgi yang mendukung/sesuai. Dengan cara seperti ini doa dapat diungkapkan secara lebih menarik, dan misteri liturgi, yang sedari hakikatnya bersifat hirarkis dan jemaat, dinyatakan secara lebih jelas.

Partisipasi umat dalam bernyanyi sangat penting, sebab dalam perayaan Ekaristi jangan sampai umat beriman hadir sebagai orang luar atau penonton yang bisu (lih. SC 48). Dengan ikut bernyanyi, orang akan dibantu untuk membangun suasana hati dan keyakinan batin yang lebih besar untuk berelasi dengan Allah. Persoalannya adalah bagaimana pemilihan dan penggunaan nyanyian liturgi yang mendukung penghayatan umat, khususnya bagi kaum muda? Apakah semua nyanyian liturgi yang ada dalam Gereja cukup membantu umat menghayati perayaan Ekaristi?

Menurut penulis, nyanyian liturgi yang tepat tidak hanya menyangkut kesesuaian syair, melodi, tema, dan penggunaannya saja dalam bagian perayaan, tetapi juga menyangkut jiwa lagunya yang sesuai dengan jiwa umat yang merayakannya. Hal itu secara tidak langsung ditegaskan dalam pedoman liturgi bahwa Ekaristi dirayakan sesuai dengan keadaan umat setempat (lih. PUMR 18). Perhatian terhadap keadaan dan kekhususan umat sangat penting demi mewujudkan partisipasi umat beriman dalam perayaan Ekaristi menurut tugas dan peran masing-masing, serta dapat memetik buah hasil Ekaristi sepenuh-penuhnya ( $b d k$. PUMR 17 dan 20). Maka, seluruh perayaan hendaknya dirancang sedemikian rupa sehingga umat yang hadir dapat berpartisipasi secara sadar, aktif, dan penuh, yakni berpatisipasi dengan jiwa dan raganya, serta dikobarkan dengan iman, harapan, dan kasih (PUMR 18). Penulis merasa bahwa usaha tersebut juga termasuk bagaimana merancang sedemikian rupa sebuah perayaan yang diikuti oleh umat, khususnya kaum muda, dan bagaimana mereka dapat berpartisipasi dengan jiwa dan raganya, serta dikobarkan dengan iman, harapan, dan kasih dalam perayaan Ekaristi.

Dalam perayaan Ekaristi, Umat Allah merayakan iman akan Kristus yang sengsara, wafat, dan bangkit menang atas maut. Dalam perayaan itu, Gereja tidak hanya menghadirkan misteri Kristus secara verbal (sabda) saja, tetapi - dalam Roh Kudus membawa umat masuk lebih intim dengan seluruh pikiran dan hati ke dalam misteri Paskah Kristus itu sendiri. ${ }^{22}$ Bagi umat di kalangan orang muda, musik memiliki peran penting untuk mengekspresikan jiwanya dalam menghayati perayaan Ekaristi. Dalam arti tersebut Bosco Da Cunha berpendapat bahwa sebagai tugas pelayanan, musik liturgi harus melayani orang muda, dalam arti memperhitungkan ciri khas jiwa mereka. ${ }^{23}$ Musik yang mewakili jiwa orang muda akan lebih membantu mereka masuk lebih intim dengan seluruh pikiran dan hati ke dalam misteri Paskah Kristus. Hal tersebut sangat dimungkinkan karena musik liturgi memiliki beberapa fungsi, salah satunya adalah fungsi transendental. ${ }^{24}$

Dalam fungsi transendental, Edward Foley mencatat bahwa musik memiliki empat karakteristik yang khas, yakni: musik selalu terikat oleh waktu, musik adalah tanda kehadiran personal, musik bersifat dinamis, dan musik berciri intangible. ${ }^{25}$ 
Fungsi transendental dari musik liturgi, memungkinkan seseorang yang entah mendengarkan atau pun menyanyikannya dapat berelasi dengan Allah secara lebih dekat. ${ }^{26}$ Tentu hal tersebut mengandaikan sebuah musik liturgi yang sesuai dengan budaya umat setempat. Dalam hal ini, budaya orang muda yang sudah terbiasa hidup dengan suasana musik pop, akan lebih bisa menerima musik liturgi dengan gaya pop dari pada musik liturgi klasik. Apalagi jika syairnya tidak dapat ditangkap dengan baik maka penghayatan akan pesan perayaan, di mana musik menjadi bagian integral dari liturgi, kurang atau bahkan tidak bisa dipahami oleh OMK.

\section{TANTANGAN DAN PELUANG BAGI PENGEMBANGAN MUSIK LITURGI}

Bunda Gereja sangat menginginkan supaya semua orang beriman dibimbing ke arah keikutsertaan yang sepenuhnya, sadar dan aktif dalam perayaan-perayaan liturgi (SC 14). Selain hal itu merupakan tuntutan dari hakikat liturgi sendiri, partisipasi tersebut juga merupakan hak serta kewajiban umat kristiani. Oleh karenanya, segala upaya dan usaha supaya umat beriman berpartisipasi dalam perayaan liturgi sangat didorong oleh konsili, bahkan memperoleh perhatian yang terbesar. Hal ini berlaku secara khusus bagi partisipasi kaum muda dalam merayakan Ekaristi, mengingat bahwa Gereja sangat membutuhkan peran orang muda. ${ }^{27}$ Orang muda yang berciri dinamis akan semakin menampakkan wajah Gereja muda yang hidup dan dimanis pula. Akan tetapi, keterlibatan orang muda tersebut perlu diimbangi dan didasari dengan pemahaman iman yang kuat. Dalam hal ini pemahaman mengenai liturgi dan musik liturgi.

Pemahaman mengenai liturgi sangat penting oleh karena liturgi menjadi sumber dan puncak hidup kaum beriman. Pemahaman yang benar tentang liturgi akan semakin mengembangkan partisipasi aktif jemaat beriman. Sacrosanctum Concilium artikel 113 menyatakan bahwa perayaan Ekaristi dapat menjadi lebih agung, bila dirayakan dengan nyanyian yang meriah, dilayani oleh para petugas liturgi dan umat berpartisipasi secara aktif. Dalam rangka gerak partisipasi tersebut, instruksi liturgi mengingatkan bahwa kaum beriman hendaknya diajar untuk memadukan diri secara batin dengan apa yang dinyanyikan oleh petugas atau kor, sehingga dengan mendengarkan, mereka sendiri bisa mengangkat hati ke hadapan Allah (MS 15). Maka pendidikan liturgi mutlak harus diusahakan demi mewujudkan cita-cita konstitusi liturgi, yakni memajukan partisipasi kaum beriman dalam perayaan liturgi.

Instruksi musik suci mengingatkan bahwa di antara kaum beriman, para anggota perkumpulan religius awam harus lebih diperhatikan dalam pemberian instruksi mengenai musik ibadat, supaya mereka bisa menunjang dan meningkatkan partisipasi umat dengan lebih berdaya guna (MS 18). Selain itu pembinaan seluruh umat dalam menyanyi hendaknya ditangani dengan serius dan penuh kesabaran bersama dengan pembinaan liturgi sesuai dengan usia, situasi, cara hidup kaum beriman, serta tingkat perkembangan religius mereka. Penulis merasa bahwa hal ini perlu diusahakan dan dilaksanakan sejak awal pendidikan di Sekolah Dasar. Perlu adanya perhatian dari para pendidik untuk mengajarkan tentang liturgi dan musik liturgi untuk para pelajar, tentu dengan cara dan metode yang lebih menarik dan bisa dengan mudah diterima oleh para pelajar.

Satu hal yang perlu dilakukan dalam rangka pembinaan mengenai liturgi dan musik liturgi kepada para pelajar adalah dengan selalu menekankan bahwa liturgi adalah satu-satunya kekayaan Gereja yang sangat agung. Maka segala sesuatunya perlu dipersiapkan dengan baik termasuk penggunaan nyanyian-nyanyian yang sesuai. Berbagai metode pengajaran yang kas bagi orang muda juga bisa dilakukan, misalnya: (1) Membuat website liturgi yang lebih menarik dengan menampilkan gambar-gambar aktivitas orang muda dalam musik liturgi. (2) Membuat kelompok-kelompok diskusi yang bisa diikuti oleh kaum muda pecinta musik liturgi. Untuk zaman sekarang kelompok ini dapat dipermudah konektivitasnya melalui layanan jaringan sosial, seperti misalnya: Whatsapp, Line, Facebook, Instagram, Twitter, dll. (3) Melaksanakan kegiatan camping bagi para aktivis koor 
orang muda dengan tentu saja diisi berbagai materi mengenai pembinaan liturgi dan musik liturgi. Bagi penulis peluang inilah yang bisa dikembangkan untuk dilakukan kedepannya.

Penulis memberikan saran juga kepada tim liturgi paroki tentang perlunya diadakan kegiatan pembinaan dan pendidikan secara intensif kepada orang muda mengenai liturgi, khususnya tentang musik dan nyanyian liturgi. Kegiatan ini menjadi tanggung jawab tim liturgi paroki yang bekerja sama dengan komisi liturgi kevikepan atau keuskupan. Pemahaman yang baik dan benar tentang perayaan liturgi dan makna musik liturgi, akan menjadi pondasi yang kuat bagi partisipasi OMK. Gerak dan spirit partisipasi yang aktif tidak melulu hanya demi aktualisasi diri, tetapi lebih dari itu dan yang paling penting adalah bahwa spirit partisipasi aktif muncul dari hak dan kewajiban oleh karena kesadaran diri sebagai OMK, bagian dari umat Allah, sebagai "bangsa terpilih, imamat rajawi, bangsa kudus, umat kepunyaan Allah sendiri" dan berdasarkan rahmat baptis yang telah diterimanya (lih. SC 14, 1Ptr 2:9; 2:45).

Kegiatan pembinaan dan pendidikan liturgi itu dapat dilaksanakan dengan mengumpulkan para aktivis kor, pengarang lagu, dan pemain musik dalam suatu seminar musik liturgi yang didampingi oleh para ahli liturgi dan musik liturgi. Tidak hanya berhenti dengan kegiatan seminar saja, penulis menyarankan supaya dijalin komunikasi antar mereka dalam suatu wadah paguyuban, bahkan bisa dengan memanfaatkan sarana teknologi informasi yang ada, misalnya dengan membuat group melalui jejaring sosial seperti misalnya: Whatsapp, Facebook, Instagram, twitter, dan lain sebagainya. Paguyuban ini bisa menjadi sarana bagi para aktivis kor, pengarang lagu, dan pemain musik untuk saling berdiskusi dan mencari solusi bagi pengembangan nyanyian liturgi. Tentu saja pengambil kebijakan ada pada otoritas Gereja, dalam hal ini Komlit KWI maupun keuskupan. Maka segala sesuatunya harus tetap dikomunikasikan bersama dengan otoritas Gereja.
Terkait dengan adanya tantangan sosialisasi yang tidak mudah, Orang muda sangat membutuhkan sosialisasi yang tegas dan intensif mengenai nyanyian liturgi yang baik. Di sini maksud dari sosialisasi yang tegas adalah bagaimana penjelasan yang diberikan oleh otoritas Gereja dan pihak yang berwenang dapat satu suara dan tidak berbeda-beda, baik dalam kebijakan maupun keputusannya. Maka dalam proses sosialisasi tersebut sangat dibutuhkan kerjasama yang baik dari semua pihak, baik otoritas Gereja setempat (tingkat keuskupan maupun kevikepan) bersama dengan umat, dalam hal ini para pengurus Dewan Paroki. Sosialisasi juga menyangkut bagaimana OMK menerima pengajaran mengenai musik dan nyanyian liturgi. Adanya pembinaan dan pengajaran tentang liturgi akan membantu OMK untuk semakin mengetahui dan memahami dengan baik dan benar makna serta fungsi nyanyian liturgi dan bagianbagian perayaan liturgi. Pengetahuan dan pemahaman yang baik dan benar mengenai hal itu juga akan mendorong partisipasi aktif umat dalam perayaan liturgi secara baik dan benar pula.

Spirit kebebasan modern mendorong munculnya para pengarang lagu bahkan dari kalangan orang muda. Peluang tersebut perlu ditangkap dan dikelola dengan baik supaya hasil karya cipta mereka merupakan nyanyian liturgi yang baik dan berkualitas. Maka perlu adanya pembinaan terhadap para pengarang nyanyian liturgi. Komisi liturgi sebagai otoritas resmi (lih. SC 44-46), yang bertanggung jawab terhadap jalannya pelaksanaan kegiatan perayaan liturgi Gereja setempat (tingkat nasional maupun keuskupan), perlu secara aktif melakukan pembinaan liturgi khususnya kepada para pengarang lagu liturgi. Baik juga dibentuk tim yang bertugas mengawal perkembangan nyanyian liturgi yang semakin hari dirasa cukup marak beredar di kalangan umat. Tim ini diberikan tanggung jawab secara khusus untuk mewadahi dan menjadi sarana bagi para pengarang lagu untuk mendapatkan nihil opstat dan imprimatur dalam penggunaan nyanyian liturgi yang diciptakannya. Tim ini juga bertanggung jawab dalam menginventarisasi khasanah nyanyian liturgi yang ada dan mendorong sosialisasi peng- 
gunaannya oleh umat setiap kali berliturgi, khususnya dalam perayaan Ekaristi.

Komisi liturgi juga perlu bekerja sama dengan Dewan Paroki, dalam hal ini para Koordinator Tim Kerja (KTK) kor maupun liturgi, yang menjadi garda terdepan bagi pelaksanaan perayaan liturgi bersama umat. Kerja sama tersebut menyangkut persoalan bagaimana para pengarang lagu yang ada di wilayah parokinya masing-masing, bisa mendapatkan wadah untuk berekspresi mengembangkan karya musik liturgi yang diciptakannya secara baik dan benar. Hal ini sangat penting diperhatikan oleh karena banyaknya karangan lagu-lagu (baik rohani maupun nyanyian liturgi) yang diciptakan. Oleh karena itu para pengarang lagu juga harus didorong untuk setia terhadap panggilannya dalam menciptakan nyanyian liturgi dengan cara bekerja sama dengan otoritas Gereja yang berwenang.

Masih adanya umat yang menggunakan bahasa daerah dalam perayaan liturgi menjadi tantangan sekaligus peluang bagi pelestarian budaya lokal. Kebutuhan terhadap tersedianya khasanah nyanyian liturgi kaum muda yang berbahasa daerah (misalnya: nyanyian liturgi berbahasa Jawa) sangat dirindukan oleh umat, khususnya umat di paroki-paroki yang masih setia menggunakan bahasa daerah dalam perayaan liturginya. Oleh karena itu Komisi liturgi Gereja setempat perlu segera menjawab kebutuhan tersebut dengan mendorong para pengarang lagu untuk berkreasi menciptakan nyanyian-nyanyian liturgi kaum muda berbahasa daerah.

Banyaknya kegiatan-kegiatan bagi Orang Muda Katolik (OMK) akhir-akhir ini juga menjadi kesempatan yang baik untuk mendorong mereka terbuka terhadap pendidikan liturgi. Mereka perlu didorong untuk selalu mengetahui makna liturgi, khususnya kepada para penggerak kelompok-kelompok orang muda, para koordinator, yang biasanya menentukan suatu kebijakan di tingkat mereka. Hendaknya para koordinator, pelatih kor, maupun pengurus OMK bersedia untuk belajar dan mempelajari liturgi, khususnya musik liturgi. Penulis menyarankan suapa ada gerakan untuk mengajak orang muda mencari informasi sebanyak-banyaknya mengenai pelajaran liturgi, bisa melalui buku-buku liturgi, majalah, atau pun internet. Namun, dalam mencari sumber di internet harus memilih sumber informasi yang benar dan dapat dipertanggungjawabkan, atau bertanya kepada narasumber yang berkompeten. Tidak berhenti di tingkat para koordinator OMK saja, tetapi mereka juga mengajarkannya kepada para anggota mereka, terlebih bagi informasi dan sosialisasi mengenai adanya nyanyian liturgi kaum muda, seperti misalnya dari buku BBT.

\section{PENUTUP}

Buku Bernyanyilah Bagi Tuhan (BBT) yang berisi kumpulan nyanyian liturgi kaum muda kiranya sangat diterima oleh kaum muda. Hadirnya nyanyian-nyanyian liturgi dalam buku tersebut cukup memberi pengaruh yang positif terhadap penghayatan iman kaum muda dalam perayaan Ekaristi. Pengaruh tersebut ditampakkan dalam semangat mereka untuk terlibat secara aktif, berpartisipasi dalam perayaan Ekaristi. Gerak partisipasi mereka terdukung oleh karena nyanyian liturgi BBT sangat cocok bagi kaum muda. Bahkan nyanyian liturgi BBT membuka kemungkinan untuk dapat diiringi dengan berbagi alat musik, sehingga mereka yang berbakat memainkan alat musik dapat bergabung bersama dengan kelompok kor yang menyanyikannya.

Kehadiran nyanyian liturgi buku BBT memang memberi pengaruh yang posistif bagi penghayatan iman kaum muda. Namun demikian proses pengembangannya perlu dilakukan terus menerus, mengingat bahwa semakin banyaknya nyanyian liturgi baru yang muncul dan beredar di kalangan umat. Hal ini menjadi tantangan sekaligus peluang bagi Gereja, dalam hal ini otoritas yang berwenang perlu memberi wadah kepada para aktivis muda Gereja dalam mengungkapkan ekspresi mereka. Maka kemajuan teknologi informasi dan telekomunikasi dapat dimanfaatkan sebagai sarana untuk membentuk paguyuban dalam berdiskusi dan berbagi.

Pendidikan dan pembinaan liturgi, khususnya nyanyian liturgi bagi kaum muda juga sangat dibutuhkan. Orang muda perlu 
dibimbing dan dibekali mengenai makna liturgi dan nyanyian liturgi sehingga gerak partisipasi mereka dalam perayaan Ekaristi memiliki pondasi yang baik. Hal ini juga untuk mencegah terjadinya pelanggaranpelanggaran yang justru mengaburkan makna penting perayaan Liturgi.

\section{CATATAN AKHIR}

1 Khasanah nyanyian liturgi yang sudah ada pada waktu itu misalnya adalah nyanyian liturgi yang ada dalam buku Madah Bakti dan Puji Syukur.

2 Philips Tangdilintin, Pembinaan Generasi Muda, Kanisius, Yogyakarta 2008, 27-28.

3 Lucien Deiss, Vision of Liturgy and Music for a New Century, The Liturgical Press, Collegeville Minnesota 1996, 4.

4 Lucien Deiss, Vision of Liturgy and Music for a New Century, 5.

5 Lih. Gerard Dennis Gill, Music in Catholic Liturgy: A Pastoral and Theological Companion to Sing to the Lord, Hillenbrand Books, Chocago Illinois 2009, 23-24.

6 Karl-Edmund Prier \& Paul Widyawan, Roda Musik liturgi, PML, Yogyakarta 2011, 22.

7 C.H. Suryanugraha, OSC., Melagukan Liturgi Menyanyikan Misa, Kanisius, Yogyakarta 2015, 18.

8 "Liturgical worship is given a more noble form when it is celebrated in song, with the ministers of each degree fulfilling their ministry and the people participating in it. Indeed, through this form, prayer is expressed in a more attractive way, the mystery of the liturgy, with its hierarchical and community nature, is more openly shown, the unity of hearts is more profoundly achieved by the union of voices, minds are more easily raised to heavenly things by the beauty of the sacred rites, and the whole celebration more clearly prefigures that heavenly liturgy which is enacted in the holy city of Jerusalem".

9 Jan Michael Joncas, From Sacred Song to Ritual Music: Twentieth-Century Understandings of Roman Catholic Worship Music, Liturgical Press, Collegeville 1997, 40-42.

10 Yohanes Paulus II, Surat Kepada Para Artis, Dokpen. KWI, Jakarta 2000, 28.

11 C.H. Suryanugraha, OSC., Melagukan Liturgi Menyanyikan Misa, 22.

12 Yohanes Paulus II, Surat Kepada Para Artis, 17.

13 J. Gelineau, Die Music im Christlichen Gottesdienst, 57-58, seperti dikutip oleh Dieter Mack, Sejarah Musik 4, PML, Yogyakarta 1995, 244.

14 Dieter Mack, Sejarah Musik 4, 245.

15 Choral Gregorian adalah pola dasar dalam ritual agama Katolik.

16 Dieter Mack, Sejarah Musik 4, 245.

17 Bdk. Philips Tangdilintin, Pembinaan Generasi Muda, 27-28.

18 Dieter Mack, Sejarah Musik 4, 245.

\section{Antonius Joko Hermawan}

Lulusan Program Magister Teologi, Fakultas Teologi Universitas Sanata Dharma, Yogyakarta.

Email:frjokohermawan@gmail.com
19 Bdk. Komlit KAS, Benyanyilah Bagi Tuhan, Kanisius, Yogyakarta 2009, xiii.

20 Reynaldo Antoni Haryanto, Peran Musik Suci Bagi Partisipasi Umat Dalam Liturgi Menurut Dokumen Liturgi Tahun 1963-2003, Tesis Magister Teologi USD, Yogyakarta 2013, 110.

21 Pius XII, Musicae Sacrae Disciplinae, 1955.

22 Colman O'neill, General Principles, dalam "Vatikan II - The Liturgi Constitution", Scepter Publisher, Dublin 1964, 30.

23 Bosco da Cunha, "Musik Liturgi Melayani Orang Muda Katolik", Majalah Liturgi KWI 4 (2013), 2425

24 Dari pernyataan MS 5, Joncas menemukan lima fungsi musik liturgi, yakni: fungsi dekoratif, deferensiatif, unitatif, transcendental, dan eskatologis. (Lih. Jan Michael Joncas, From Sacred Song to Ritual Music: Twentieth-Century Understandings of Roman Catholic Worship Music, 40-42)

25 Lih. E. Foley, Natan, D. Mitcell, Joanne, M. Pierce (eds), Liturgical Music: A Commentary on the General Instruction of the Roman Missal, The Liturgical Press, Collegeville Minnesota 2007, 865.

26 Lih. Reynaldo Antoni Haryanto, Peran Musik Suci, 130.

27 "Gerejamembutuhkan anda, antusias anda, kreativitas anda, dan sukacita yang begitu khas dari anda, orang muda Katolik" (Pesan Paus Fransiskus dalam Misa Penutupan World Youth Day di Pantai Copacabana, Rio De Jenairo Brazil).

\section{DAFTAR PUSTAKA}

\section{Buku:}

Deiss, L. Vision of Liturgy and Music for a New Century. Collegeville Minnesota: The Liturgical Press, 1996.

Dennis, G.G. Music in Catholic Liturgy: A Pastoral and Theological Companion to Sing to the Lord. Chocago Illinois: Hillenbrand Books, 2009.

Dieter M., Sejarah Musik 4. Yogyakarta: PML, 1995. 
Foley, E., Natan, D. Mitcell, Joanne, M. Pierce (eds). Liturgical Music: A Commentary on the General Instruction of the Roman Missal. Collegeville Minnesota: The Liturgical Press, 2007.

Haryanto, R.A. Peran Musik Suci Bagi Partisipasi Umat Dalam Liturgi Menurut Dokumen Liturgi Tahun 1963-2003. Yogyakarta: Tesis Magister Teologi USD, 2013.

Joncas, J.M. From Sacred Song to Ritual Music:Twentieth-Century Understandings of Roman Catholic Worship Music, Collegeville: Liturgical Press, 1997.

Komlit KAS. Benyanyilah Bagi Tuhan. Yogyakarta: Kanisius, 2009.

O'neill, C. General Principles, dalam "Vatikan II - The Liturgi Constitution”. Dublin: Scepter Publisher, 1964.
Pius XII. Musicae Sacrae Disciplinae. 1955.

Philips Tangdilintin, P. Pembinaan Generasi Muda. Yogyakarta: Kanisius, 2008.

Prier, K-E \& Paul Widyawan. Roda Musik liturgi. Yogyakarta: PML, 2011.

Suryanugraha, C.H. Melagukan Liturgi Menyanyikan Misa. Yogyakarta: Kanisius, 2015.

Yohanes Paulus II, Surat Kepada Para Artis, Dokpen. Jakarta: KWI, 2000.

\section{Majalah:}

Bosco da Cunha, "Musik Liturgi Melayani Orang Muda Katolik", Majalah Liturgi KWI 4 (2013) 